\title{
Proposal for Two New Genera, Brevibacillus gen. nov. and Aneurinibacillus gen. nov.
}

\author{
OSAMU SHIDA, ${ }^{1 *}$ HIROAKI TAKAGI, ${ }^{1}$ KIYOSHI KADOWAKII, ${ }^{1}$ AND KAZUO KOMAGATA ${ }^{2}$ \\ Research Laboratory, Higeta Shoyu Co., Ltd., Choshi, Chiba 288, ${ }^{1}$ and Department of Agricultural Chemistry, Faculty \\ of Agriculture, Tokyo University of Agriculture, Setagaya-ku, Tokyo $156,{ }^{2}$ Japan
}

\begin{abstract}
16S rRNA gene sequences of the type strains of 11 species belonging to the Bacillus brevis and Bacillus aneurinolyticus groups were determined. On the basis of the results of gene sequence analyses, these species were separated into two clusters. The $B$. brevis cluster included 10 species, namely, Bacillus brevis, Bacillus agri, Bacillus centrosporus, Bacillus choshinensis, Bacillus parabrevis, Bacillus reuszeri, Bacillus formosus, Bacillus borstelensis, Bacillus laterosporus, and Bacillus thermoruber. Bacillus aneurinolyticus and Bacillus migulanus belonged to the $B$. aneurinolyticus cluster. Moreover, the two clusters were phylogenetically distinct from other Bacillus, Amphibacillus, Sporolactobacillus, Paenibacillus, and Alicyclobacillus species. On the basis of our data, we propose reclassification of the $B$. brevis cluster as Brevibacillus gen. nov. and reclassification of the $B$. aneurinolyticus cluster as Aneurinibacillus gen. nov. By using 16S rRNA gene sequence alignments, two specific PCR amplification primers were designed for differentiating the two new genera from each other and from other aerobic, endospore-forming organisms.
\end{abstract}

The aerobic, rod-shaped, endospore-forming genus Bacillus is a systematically diverse taxon (5). The members of this genus exhibit a wide range of DNA base compositions, and the major amino acid compositions of the cell walls of these organisms vary $(6,22,32)$. Analyses of $16 \mathrm{~S}$ rRNA gene sequences have identified at least eight phylogenetic groups in the genus $B a$ cillus $(2,3,7,20,22-24,33,38)$. Two of these groups have been reclassified as new genera. One genus, the genus Alicyclobacillus (38), consists of thermoaciduric species that contain rarely encountered cellular $\omega$-cyclic fatty acids. The other new genus, the genus Paenibacillus (3), was distinguished on the basis of the results of slot blot hybridization in which a specific probe was used.

Recent taxonomic studies have shown that strains previously assigned to Bacillus brevis should be separated into nine species, namely, Bacillus brevis, Bacillus agri, Bacillus centrosporus, Bacillus choshinensis, Bacillus parabrevis, Bacillus reuszeri, Bacillus formosus, Bacillus borstelensis, and Bacillus migulanus $(18,19,28,29,34)$. A closely related species, Bacillus aneurinolyticus, has also been revived by Shida et al. (30). On the basis of the results of comparisons of their phenotypic characteristics, chemosystematic profiles, and conserved specific Slayer proteins, the 10 species mentioned above were separated into two groups $(28-30,34)$. One group, designated the Bacillus brevis group, included all of the species derived from $\mathrm{Ba}$ cillus brevis except Bacillus migulanus. The other group, called the Bacillus aneurinolyticus group, included Bacillus aneurinolyticus and Bacillus migulanus. These groups corresponded closely to the groups generated by a numerical analysis of electrophoretic whole-cell protein patterns (31). Moreover, the results of phylogenetic studies demonstrated that Bacillus laterosporus and Bacillus thermoruber fell into the "Bacillus brevis" cluster or rRNA group $4(2,7,23,24)$, and Bacillus aneurinolyticus was judged to be closely related to the Bacillus brevis clade $(2,7)$.

The observations described above raised interesting ques-

* Corresponding author. Mailing address: Research Laboratory, Higeta Shoyu Co., Ltd., 2-8 Chuo-cho, Choshi, Chiba 288, Japan. Phone: 81-479-22-1180. Fax: 81-479-24-3422. Electronic mail address: LDX05744@niftyserve.or.jp.

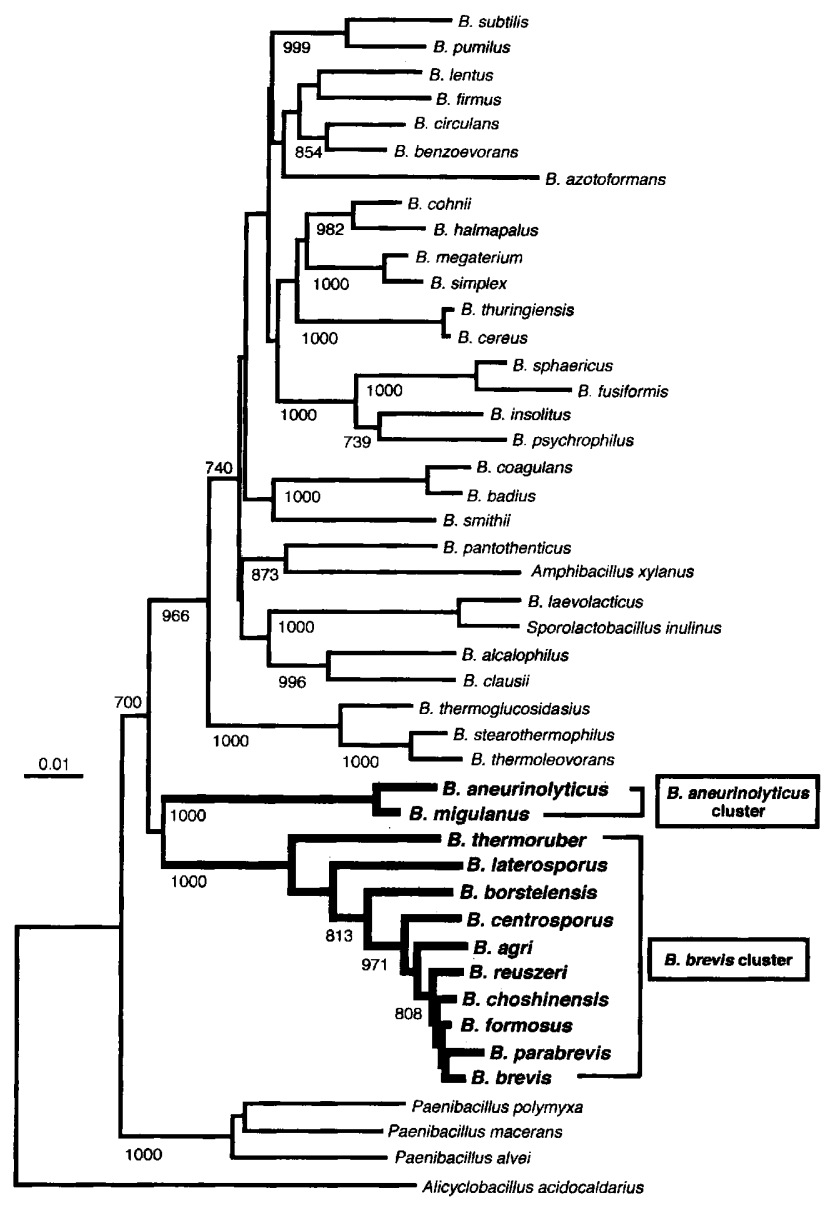

FIG. 1. Phylogenetic relationships of Bacillus species and some related organisms based on 16S rRNA gene sequences. The branching pattern was generated by the neighbor-joining method. The numbers are bootstrap values which are greater than 700 . The thick lines indicate the Bacillus brevis cluster and the Bacillus aneurinolyticus cluster. Bar $=0.01$ nucleotide substitution per site. 
TABLE 1. Bacterial strains used in this study

\begin{tabular}{|c|c|c|c|}
\hline Strain & Source $^{a}$ & History ${ }^{b}$ & $\begin{array}{c}\text { Nucleotide } \\
\text { sequence } \\
\text { accession } \\
\text { no. }\end{array}$ \\
\hline \multicolumn{4}{|c|}{ 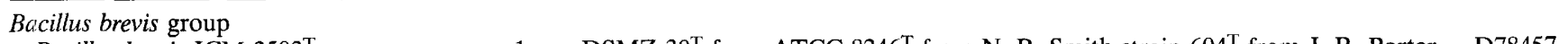 } \\
\hline Bacillus brevis JCM $2503^{\mathrm{T}}$ & 1 & $\begin{array}{l}\text { DSMZ } 30^{\mathrm{T}} \text { from ATCC } 8246^{\mathrm{T}} \text { from N. R. Smith strain } 604^{\mathrm{T}} \text { from J. R. Porter } \\
\text { from NCTC } 2611^{\mathrm{T}} \text { from W. W. Ford strain } 27 \mathrm{~B}\end{array}$ & D78457 \\
\hline Bacillus agri NRRL NRS- $1219^{\mathrm{T}}$ & 2 & C. Lamanna strain 13 & D78454 \\
\hline Bacillus centrosporus NRRL NRS- $664^{\mathrm{T}}$ & 2 & B. S. Henry strain 120 & D78458 \\
\hline Bacillus choshinensis HPD52 ${ }^{\mathrm{T}}$ & 3 & $\begin{array}{l}\text { H. Takagi et al., from soil, protein producer }\left(=\mathrm{JCM} 8505^{\mathrm{T}}=\mathrm{IFO}\right. \\
\left.15518^{\mathrm{T}}=\text { CIP } 103838^{\mathrm{T}}=\text { DSMZ } 8552^{\mathrm{T}}\right)\end{array}$ & D78459 \\
\hline Bacillus parabrevis IFO $12334^{\mathrm{T}}$ & 4 & $\begin{array}{l}\text { ATCC } 10027^{\mathrm{T}} \text { from N. R. Smith strain } 605^{\mathrm{T}} \text { from J. R. Porter from G. } \\
\text { Bredemann }\left(=\text { JCM } 8506^{\mathrm{T}}=\text { CIP } 103840^{\mathrm{T}}\right)\end{array}$ & D78463 \\
\hline Bacillus reuszeri NRRL NRS- $1206^{\mathrm{T}}$ & 2 & H. W. Reuszer Army strain $39\left(=\right.$ JCM $9170^{\mathrm{T}}=$ IFO $15719^{\mathrm{T}}=$ CIP $\left.104543^{\mathrm{T}}\right)$ & D78464 \\
\hline Bacillus formosus NRRL NRS- $863^{\mathrm{T}}$ & 2 & $\begin{array}{l}\text { J. R. Porter from G. Bredemann }\left(=\mathrm{JCM} 9169^{\mathrm{T}}=\mathrm{IFO} 15716^{\mathrm{T}}=\mathrm{CIP}\right. \\
\left.104544^{\mathrm{T}}\right)\end{array}$ & D78460 \\
\hline Bacillus borstelensis NRRL NRS- $818^{\mathrm{T}}$ & 2 & J. R. Porter $\left(=\mathrm{JCM} 9022^{\mathrm{T}}=\mathrm{IFO} 15716^{\mathrm{T}}=\mathrm{CIP} 104545^{\mathrm{T}}\right)$ & D78456 \\
\hline Bacillus laterosporus JCM $2496^{\mathrm{T}}$ & 1 & CCM $2116^{\mathrm{T}}$ from R. E. Gordon & D78461 \\
\hline Bacillus thermoruber DSMZ $7064^{\mathrm{T}}$ & 5 & P. L. Manachini strain BT2 & $\mathrm{Z} 26921^{c}$ \\
\hline \multicolumn{4}{|l|}{ Bacillus aneurinolyticus group } \\
\hline Bacillus aneurinolyticus ATCC $12856^{\mathrm{T}}$ & 6 & $\begin{array}{l}\text { Y. Ito from R. Kimura }\left(=\operatorname{IAM} 1077^{\mathrm{T}}=\mathrm{JCM} 9024^{\mathrm{T}}=\text { IFO } 15521^{\mathrm{T}}=\mathrm{CIP}\right. \\
\left.104007^{\mathrm{T}}\right)\end{array}$ & D78455 \\
\hline Bacillus migulanus ATCC $9999^{\mathrm{T}}$ & 6 & $\begin{array}{l}\text { NCTC } 7096^{\mathrm{T}} \text { from R. Synge from Moscow, gramicidin S producer } \\
\left(=\mathrm{JCM} 8504^{\mathrm{T}}=\text { IFO } 15520^{\mathrm{T}}=\text { CIP } 103841^{\mathrm{T}}\right)\end{array}$ & D78462 \\
\hline Amphibacillus xylanus JCM $7361^{\mathrm{T}}$ & 1 & Y. Niimura strain Ep01 & D82062 \\
\hline
\end{tabular}

tions concerning the phylogenetic relationship and status of the Bacillus brevis group and the Bacillus aneurinolyticus group. To address these questions, we determined the 16S rRNA gene sequences of the species in these two groups and compared them with available homologous sequences of other Bacillus species.

\section{MATERIALS AND METHODS}

Bacterial strains. The bacterial strains used in this study are listed in Table 1. All working stock preparations except the working stock preparation for a $\mathrm{Ba}$ cillus thermoniber strain were cultured on $\mathrm{T} 2$ agar plates (37) for $24 \mathrm{~h}$ at $30^{\circ} \mathrm{C}$. The Bacillus thermoruber strain was cultured on TER/1 agar plates (17) for $24 \mathrm{~h}$ at $45^{\circ} \mathrm{C}$. The strains were stored at room temperature.

Chemosystematic characterization of Bacillus thermoruber. The isoprenoid quinones of Bacillus thermoruber DSMZ $7064^{\mathrm{T}}$ ( $\mathrm{T}=$ type strain) were analyzed by the method described by Komagata and Suzuki (16).

A Western blot (immunoblot) analysis of whole-cell proteins was performed as described by Towbin et al. (36). Rabbit antisera against the S-layer proteins of Bacillus choshinensis HPD31 and Bacillus migulanus KA S232 were prepared as described by Takagi et al. (34) and Abe and Kimoto (1), respectively.

Cloning and sequencing of 16S rRNA genes. Chromosomal DNA was prepared as described previously (34). PCR amplification of the 16S rRNA gene from chromosomal DNA was carried out by the method of Fox et al. (10). Oligonucleotides 5'-CTGGGATCCATTTACTCGAGAGTTTGATCCTGGCT CAG-3' (primer 27FC; 5' end of the 16S rRNA gene) and 5'-GGTTCCCCTA AGCTTACCTTGTTACGACTTC-3' (primer 1490RC; $3^{\prime}$ end of the 16S rRNA gene) were used as primers for PCR as described by Wisotzkey et al. (38), with some modifications. The amplified $16 \mathrm{~S}$ rRNA genes were digested with $X$ hol and HindIII and cloned into pGEM-7zf(+) (Promega Co., Madison, Wis.) that was digested with the same enzymes. The cloned plasmids were used for sequencing templates. Sequencing was carried out as described by Sanger et al. (27) by using a Taq DyeDeoxy terminator cycle sequencing kit (Perkin-Elmer Co., Foster City, Calif.) and a model ABI 373 automatic DNA sequencer (Perkin-Elmer Co.) Seven sequencing primers were used as described by Fox et al. (10).

Comparison of 16S rRNA gene sequences. Previously published 16S rRNA gene sequences were obtained from the EMBL-GenBank-DDBJ database. Multiple sequences were aligned, nucleotide substitution rates ( $K_{\text {nuc }}$ values) $(15)$ were calculated, a neighbor-joining phylogenetic tree (25) was constructed, and a bootstrap analysis with 1,000 replicates to evaluate the phylogenetic tree to- pology (8) was performed by using the CLUSTAL W program (35). Alignment gaps and unidentified base positions were not taken into account in the calculations.

Identification of strains belonging to the Bacillus brevis group and the Bacillus aneurinolyticus group by 16S rRNA gene amplification. Strains belonging to the Bacillus brevis group and the Bacillus aneurinolyticus group were identified by $16 \mathrm{~S}$ rRNA gene amplification by using specific detection primers and PCR. The sequences of forward detection primers BREV174F and ANEU506F were $5^{\prime}-\mathrm{A}$ GACCGGGATAACATAGGGAAACTTAT- $3^{\prime}$ and $5^{\prime}$-GAACCGCCGGGAT GACCTCCCGGTC-3', respectively. The sequence of reverse primer $1377 \mathrm{R}$ was 5'-GGCATGCTGATCCGCGATTACTAGC-3'; this sequence covered the conserved region of the $16 \mathrm{~S}$ rRNA gene at positions 1401 to 1377 . The primers were designed by considering aligned sequences of the $16 \mathrm{~S}$ rRNA gene.

Approximately 0.2 ng of chromosomal DNA was subjected to a PCR in a $25-\mu 1$ (total volume) reaction mixture containing $0.1 \mathrm{U}$ of $\mathrm{Ta} q$ DNA polymerase (Pharmacia Biotech, Uppsala, Sweden), $2.5 \mu$ of $10 \times$ Taq DNA polymerase buffer (Pharmacia Biotech), $4.0 \mu \mathrm{l}$ of a $1.25 \mathrm{mM}$ deoxynucleoside triphosphate solution, and $0.25 \mu \mathrm{l}$ of a solution containing forward and reverse primers at a concentration of $0.1 \mathrm{mM}$. The procedure used involved 1 cycle of denaturation for 0.5 min at $94^{\circ} \mathrm{C}, 25$ cycles consisting of denaturation for $1.0 \mathrm{~min}$ at $94^{\circ} \mathrm{C}$, annealing for $1.5 \mathrm{~min}$ at $58^{\circ} \mathrm{C}$, and extension for $1.5 \mathrm{~min}$ at $72^{\circ} \mathrm{C}$, and 1 cycle of extension for $5.0 \mathrm{~min}$ at $72^{\circ} \mathrm{C}$. The PCR products were analyzed by electrophoresis on a $1.2 \%$ agarose gel with TAE buffer (26).

Nucleotide sequence accession numbers. The 16S rRNA gene sequences determined in this study have been deposited in the DDBJ-EMBL-GenBank database under the accession numbers shown in Table 1.

\section{RESULTS}

Chemosystematic characterization of Bacillus thermoruber. The name Bacillus thermoruber was revived by Manachini et al. (17). This organism was reported to grow at 45 to $48^{\circ} \mathrm{C}$ and to produce a red pigment. Bacillus thermoruber DSMZ $7064^{\mathrm{T}}$ contained menaquinone 7 , which accounted for more than $95 \%$ of the total menaquinones.

A Western blot analysis showed that Bacillus thermoruber DSMZ $7064^{\mathrm{T}}$ contained protein that cross-reacted with antiserum against the S-layer protein of Bacillus choshinensis and 
BREV174F Primer :

Position

B. brevis :

B. agri :

B. centrosporus :

B. choshinensis :

B. parabrevis :

B. reuszeri:

B. formosus :

B. borstelensis :

B. laterosporus:

B. thermoruber:

B. subtilis :

B. firmus :

B. circulans :

B. azotoformans :

B. cohnii :

B. megaterium

B. cereus

B. sphaericus :

B. psychrophilus

B. coagulans

B. smithii:

B. pantothenticus :

A. Xylanus :

S. inulinus

B. alcalophilus :

B. stearothermophilus :

B. thermoglucosidasius

B. aneurinolyticus

B. migulanus

P. polymyxa:

$P$. alvel:

A. acidocaldarius :
5 ' -AgACCgggataACATAgGgAAACTTAT-3 '

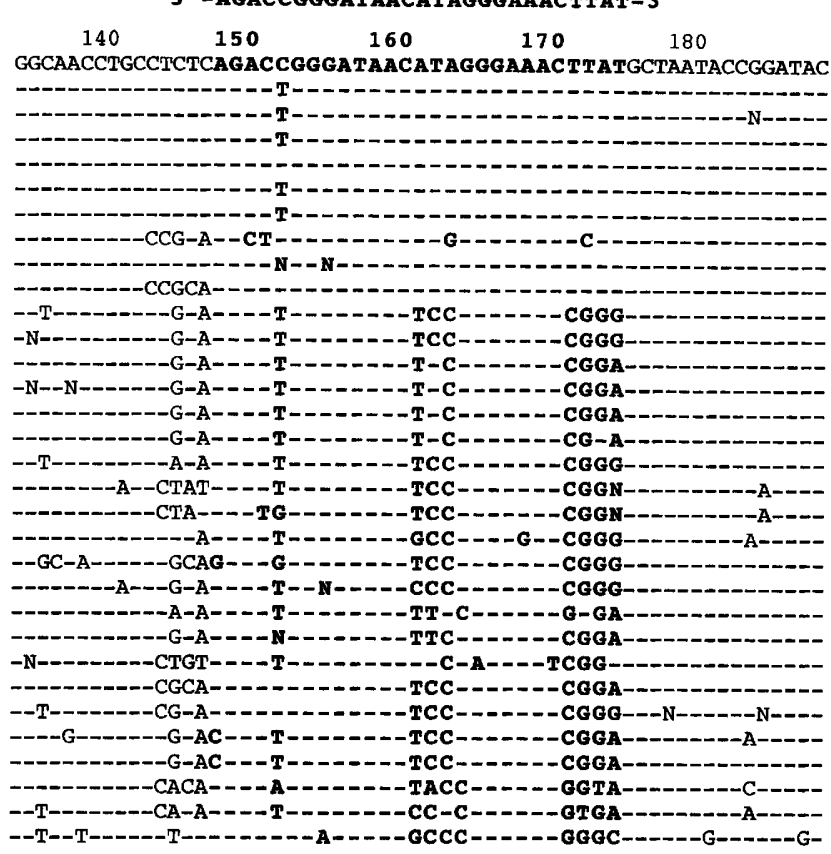

FIG. 2. Sequence of the detection primer for members of the Bacillus brevis group (the Bacillus brevis cluster) (primer BREV174F) and alignment of the 16S rRNA gene sequences of Bacillus species and related organisms. Dashes indicate nucleotides identical to nucleotides of Bacillus brevis. Boldface letters indicate nucleotides identical to the nucleotides of primer BREV174F and the primer regions of other Bacillus species and related organisms. Abbreviations: B., Bacillus; $A$. xylanus, Amphibacillus xylanus; S., Sporolactobacillus; P., Paenibacillus; A. acidocaldarius, Alicyclobacillus acidocaldarius.

not with antiserum against the S-layer protein of Bacillus migulanus (data not shown). Other chemosystematic data for $B a$ cillus thermoruber were similar to data for members of the Bacillus brevis group (28, 29, 34). Therefore, Bacillus thermoruber is a member of the Bacillus brevis group. The separate position of this organism within the Bacillus brevis group was established by its levels of DNA relatedness (data not shown), its levels of 16S rRNA gene sequence similarity (data not shown), and its DNA base composition (17).

Phylogenetic relationship. Nucleotide sequences $(1,419$ to $1,422 \mathrm{bp}$ ) of the $16 \mathrm{~S}$ rRNA genes of the type strains of Bacillus brevis, Bacillus agri, Bacillus centrosporus, Bacillus choshinensis, Bacillus parabrevis, Bacillus reuszeri, Bacillus formosus, Bacillus borstelensis, Bacillus laterosporus, Bacillus aneurinolyticus, and Bacillus migulanus were determined. These sequences were compared with those of 28 other Bacillus species, 3 Paenibacillus species, Amphibacillus xylanus (determined in this study), Sporolactobacillus inulinus, and Alicyclobacillus acidocaldarius. The levels of sequence similarity among 10 species belonging to the Bacillus brevis group (Bacillus brevis, Bacillus agri, $\mathrm{Ba}$ cillus centrosporus, Bacillus choshinensis, Bacillus parabrevis, Bacillus reuszeri, Bacillus formosus, Bacillus borstelensis, Bacillus laterosporus, and Bacillus thermoruber) were more than $93.2 \%$, and the levels of sequence similarity between these 10 species and the other species were less than $91.3 \%$ (data not shown). In addition, the level of sequence similarity between the members of the Bacillus aneurinolyticus group (Bacillus aneurinolyticus and Bacillus migulanus) was $98.6 \%$, and the levels of sequence similarity between these two species and other species were less than $91.3 \%$. All 10 species belonging to the Bacillus brevis group were placed in a robust (100\% of the bootstrap values) monophyletic cluster (the Bacillus brevis cluster), and the two species belonging to the Bacillus aneurinolyticus group were placed in another equally robust monophy- letic cluster (the Bacillus aneurinolyticus cluster) (Fig. 1). These two clusters were clearly separated from the other clusters containing Bacillus, Amphibacillus, Sporolactobacillus, Paenibacillus, and Alicyclobacillus species.

Identification of the Bacillus brevis group and the Bacillus aneurinolyticus group by $16 \mathrm{~S}$ rRNA gene amplification. The PCR primers used to detect members of the Bacillus brevis and Bacillus aneurinolyticus clusters were designed by using the $16 \mathrm{~S}$ rRNA gene sequence alignments. Primer BREV174F, which was designed to detect the Bacillus brevis cluster, covered positions 148 to 174 (Fig. 2), and primer ANEU506F, which was designed to detect the Bacillus aneurinolyticus cluster, covered positions 482 to 506 (Fig. 3). The results of 16S rRNA gene amplification of 32 Bacillus, Amphibacillus, Sporolactobacillus, Paenibacillus, and Alicyclobacillus species in which the detection primers were used are shown in Fig. 4. Using primers BREV174F and 1377R resulted in a 1.2-kb PCR fragment with the type strains of all of the species belonging to the Bacillus brevis cluster, but not with the type strains of the species belonging to other clusters. With primers ANEU506F and $1377 \mathrm{R}$, the type strains of the species belonging to the Bacillus aneurinolyticus cluster produced an amplified $0.8-\mathrm{kb}$ fragment, but the type strains of the 30 species belonging to other clusters did not. In addition, a $1.3-\mathrm{kb}$ fragment was amplified in all of the strains tested with primers $27 \mathrm{FC}$ and $1377 \mathrm{R}$ (data not shown).

\section{DISCUSSION}

In previous studies, phenotypic characteristics, chemotaxonomic profiles, and the nature of S-layer proteins intimated that there were two taxonomically distinct groups, namely, the Bacillus brevis group and the Bacillus aneurinolyticus group (18, 19, 28-30, 34). The Bacillus brevis group can be characterized 


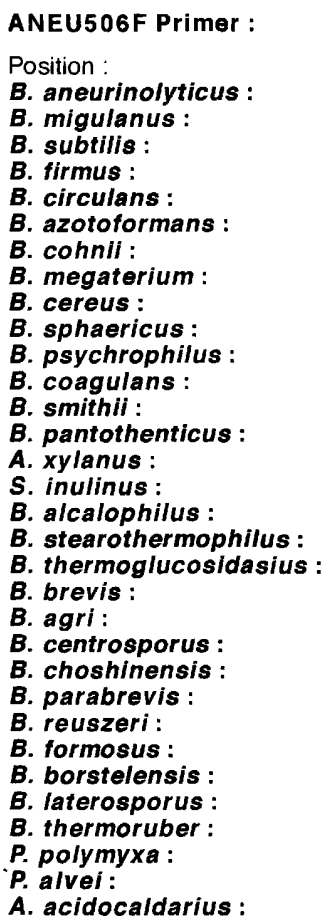

5 '-GAACCGCCGgGATGACTCCCGGTC-3'

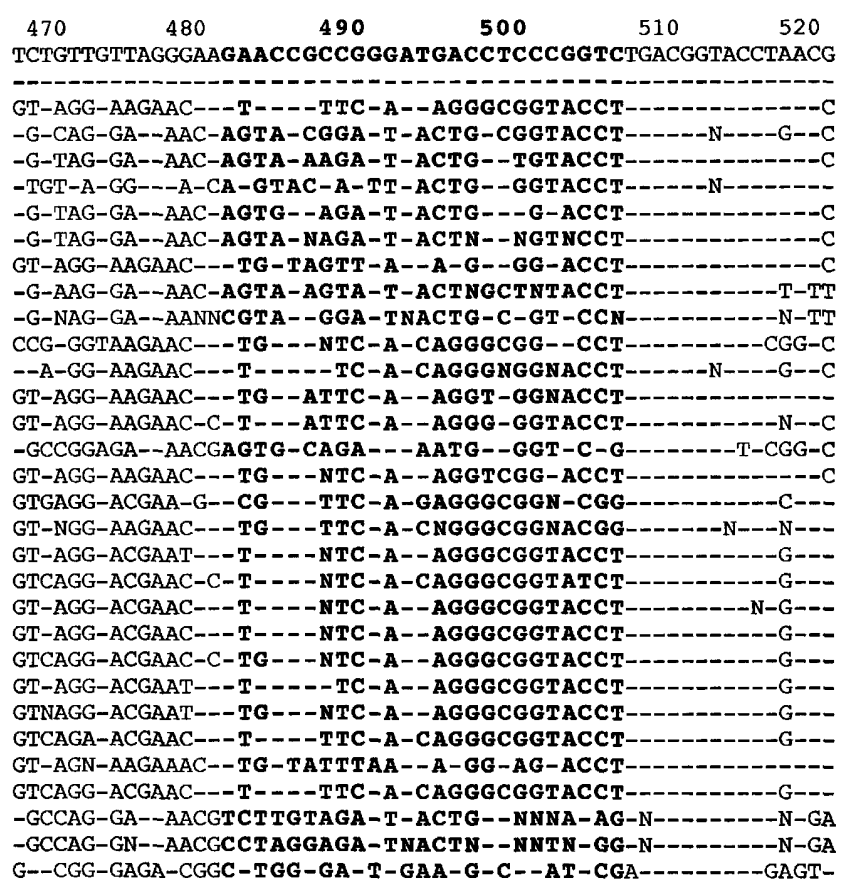

FIG. 3. Sequence of the detection primer for members of the Bacillus aneurinolyticus group (the Bacillus aneurinolyticus cluster) (primer ANEU506F) and alignment of the 16S rRNA gene sequences of Bacillus species and related organisms. Dashes indicate nucleotides identical to Bacillus aneurinolyticus nucleotides. Boldface letters indicate nucleotides identical to the nucleotides of primer ANEU506F and the primer regions of other Bacillus species and related organisms. Abbreviations are explained in the legend to Fig. 2.

by serologically related S-layer proteins. Similarly, the important characteristics of the Bacillus aneurinolyticus group are the unique serologically related S-layer proteins of the members of this group. Thiamine hydrolase-mediated decomposition of thiamine is another distinguishing trait of the Bacillus aneurinolyticus group.

In the present study, sequence analysis of the $16 \mathrm{~S}$ rRNA gene provided data that support the existence of the Bacillus brevis and Bacillus aneurinolyticus groups. For example, sequence comparisons performed with members of the Bacillus brevis group and the Bacillus aneurinolyticus group revealed intragroup similarity values of more than 93.2 and $98.6 \%$, respectively. In contrast, the levels of similarity between members of these groups and members of previously described genera were consistently less than $91.3 \%$. These intragroup and intergroup similarity values indicate that the Bacillus brevis and Bacillus aneurinolyticus groups are cohesive and distinct from each other and from previously described genera. Furthermore, examinations of the $16 \mathrm{~S}$ rRNA gene sequences also revealed sequence segments that are group specific.

The results of analyses based on $16 \mathrm{~S}$ rRNA gene sequences demonstrated that the Bacillus brevis and Bacillus aneurinolyticus groups represent two taxa that are phylogenetically distinct from each other and from the other genera studied (namely, the genera Bacillus, Sporolactobacillus, Paenibacillus, Amphibacillus, and Alicyclobacillus) (Fig. 1). Interestingly, the Bacillus brevis and Bacillus aneurinolyticus groups are more closely related to each other than to the other genera. On the basis of the accumulated phenotypic characteristics, chemosystematic profiles, 16S rRNA gene sequences, and phylogenetic data, we propose two new genera, Brevibacillus gen. nov. for the 10 species in the Bacillus brevis cluster and Aneurinibacillus gen. nov. for the 2 species in the Bacillus aneurinolyticus cluster.
Previous reports $(4,9,13,14)$ have shown that PCR amplification of $16 \mathrm{~S}$ rRNA gene fragments is useful for identification of some bacterial strains with specific primers. Forsman et al. (9) reported that this procedure was suitable and useful for rapid and specific identification of members of the genus Francisella at the genus, species, and subspecies levels. In this study, we developed a rapid method for identifying two genera, the genera Brevibacillus and Aneurinibacillus, by PCR amplification of 16S rRNA gene fragments with specific primers. The detection primers were highly specific for these genera. After strains are assigned to the genus Brevibacillus or the genus Aneurinibacillus by this method, numerical analyses based on electrophoretic whole-cell protein profiles (31) and DNADNA hybridization data $(19,28,30,34)$ are useful for identifying the organisms to the species level. In addition, the PCR amplification method is rapid, simple, and efficient. Thus, this method is recommended as a method that is convenient and useful in taxonomic studies of aerobic, endospore-forming rods.

The salient characteristics of the seven genera of aerobic, endospore-forming rods are shown in Table 2.

Description of Brevibacillus gen. nov. Brevibacillus (Bre.vi.ba.cil'lus. L. adj. brevis, short; L. dim. n. bacillus, small rod; M. L. masc. n. Brevibacillus, short, small rod.) Cells are rod shaped $(0.7$ to 0.9 by 3.0 to $5.0 \mu \mathrm{m})$. Gram positive or gram variable. Motile by means of peritrichous flagella. Ellipsoidal spores are formed in swollen sporangia. Colonies of 10 species are flat, smooth, and yellowish gray, and no soluble pigment is produced on nutrient agar.

Almost all of the species are strictly aerobic. Brevibacillus laterosporus is facultatively anaerobic.

Catalase positive (Brevibacillus thermoruber is weakly catalase positive). Oxidase variable. 


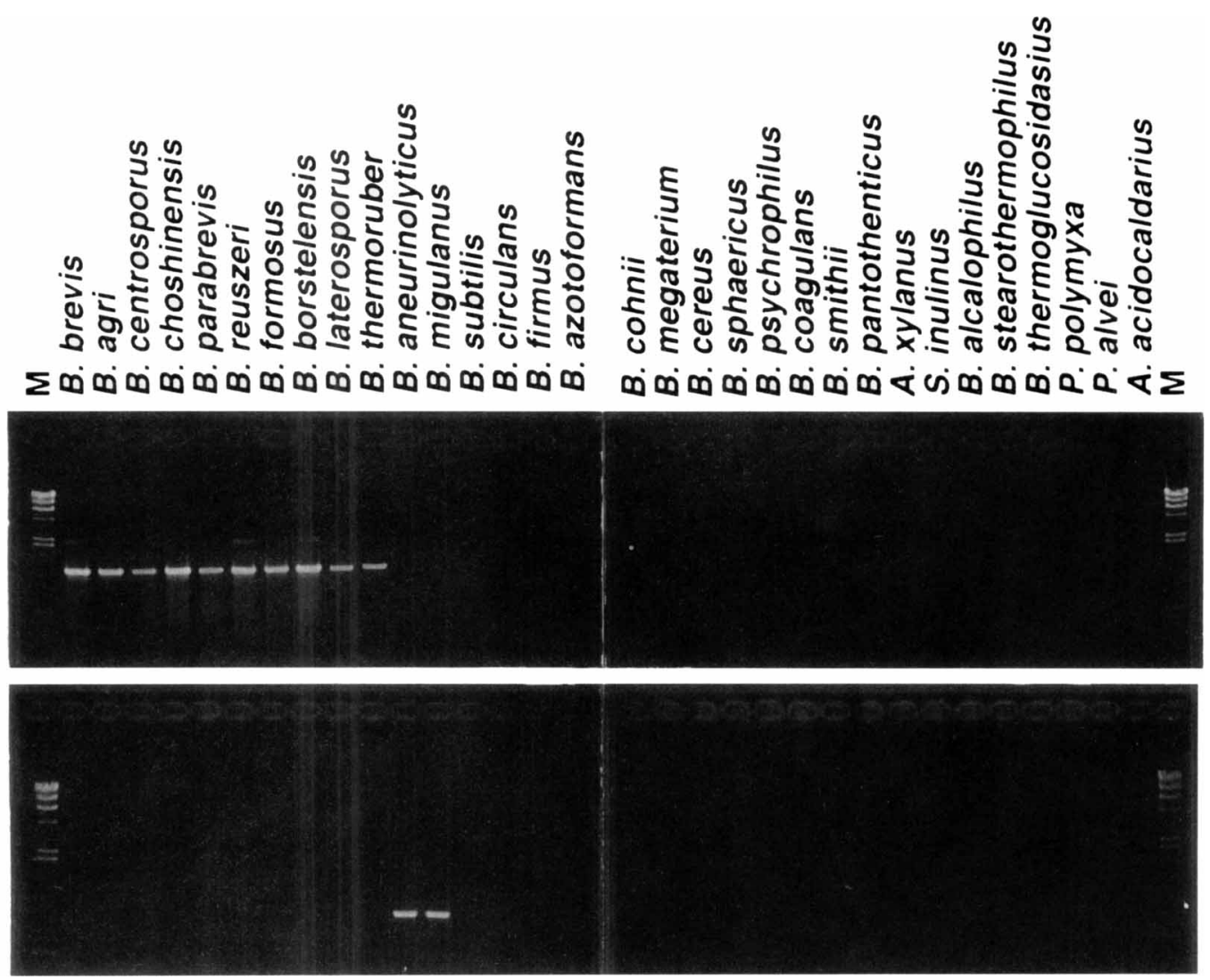

FIG. 4. Amplification of the 16S rRNA gene by PCR with detection primers. (A) Primers BREV174F and 1377R. (B) Primers ANEU506F and 1377R. All of the strains tested were type strains. Lanes M contained HindIII-digested $\lambda$ DNA as a molecular weight marker. Abbreviations are explained in the legend to Fig. 2.

The Voges-Proskauer reaction (production of acetylmethylcarbinol) is negative, and the $\mathrm{pH}$ in Voges-Proskauer broth is higher than 7.0 .

Hydrogen sulfide and indole are not produced.

Nitrate reduction to nitrite is variable.

Hydrolysis of casein, gelatin, and starch is variable.

Decomposition of tyrosine is variable.

Growth at $\mathrm{pH} 5.6$ or 5.7 and at $50^{\circ} \mathrm{C}$ is variable. Optimum growth occurs at $\mathrm{pH}$ 7.0. The optimum growth temperature of nine species (all species except Brevibacillus thermoruber) is $30^{\circ} \mathrm{C}$. The optimum growth temperature of Brevibacillus thermoruber is 45 to $48^{\circ} \mathrm{C}$. Growth is inhibited by $5 \% \mathrm{NaCl}$.

Acid but no gas is produced from various sugars.

Specific S-layer protein is present.

The major cellular fatty acids are iso- $\mathrm{C}_{15: 0}$ and anteiso- $\mathrm{C}_{15: 0}$ acids or just iso- $\mathrm{C}_{15: 0}$ acid.

The major quinone is menaquinone 7 .

The $\mathrm{G}+\mathrm{C}$ content ranges from 42.8 to $57.4 \mathrm{~mol} \%$.

The levels of 16S rRNA gene sequence similarity are more than $93.2 \%$ for the members of this genus. The 16S rRNA gene fragment is amplified by PCR by using primers BREV174F and $1377 \mathrm{R}$.

The type species is Brevibacillus brevis.

Description of Brevibacillus brevis (Migula 1900) comb. nov. The description of Brevibacillus brevis comb. nov. is identical to the descriptions given by Claus and Berkeley (5), Nakamura (18), and Takagi et al. (34). The type strain is strain JCM 2503 $(=$ ATCC $8246=$ CCM $2050=$ CIP 52.86 = DSMZ $30=$ IFO $15304=$ NRRL B-14602 = LMG 7123 = NCIMB 9372).
Description of Brevibacillus agri (Nakamura 1993) comb. nov. The description of Brevibacillus agri comb. nov. is identical to the descriptions given by Nakamura (19) and Shida et al. (29). The type strain is strain NRRL NRS-1219 (= JCM $9067=$ DSMZ $6348=$ IFO 15538).

Description of Brevibacillus centrosporus (Nakamura 1993) comb. nov. The description of Brevibacillus centrosporus comb. nov. is identical to the description given by Nakamura (19). The type strain is strain NRRL NRS-664 (= JCM $9071=$ IFO 15540).

Description of Brevibacillus choshinensis (Takagi et al. 1993) comb. nov. The description of Brevibacillus choshinensis comb. nov. is identical to the descriptions given by Takagi et al. (34) and Shida et al. (28). The type strain is strain HPD52 (= JCM $8505=$ IFO $15518=$ CIP $103838=$ DSMZ $8552=$ ATCC 51359 = NCIMB 13345).

Description of Brevibacillus parabrevis (Takagi et al. 1993) comb. nov. The description of Brevibacillus parabrevis comb. nov. is identical to the descriptions given by Takagi et al. (34) and Shida et al. (28). The type strain is strain IFO 12334 (= JCM $8506=$ CIP $103840=$ ATCC $10027=$ NCIMB 13346).

Description of Brevibacillus reuszeri (Shida et al. 1995) comb. nov. The description of Brevibacillus reuszeri comb. nov. is identical to the descriptions given by Shida et al. (28) and Nakamura (19). The type strain is strain NRRL NRS-1206 (= JCM 9170 = IFO $15719=$ CIP 104543).

Description of Brevibacillus formosus (Shida et al. 1995) comb. nov. The description of Brevibacillus formosus comb. nov. is identical to the descriptions given by Shida et al. (28) 


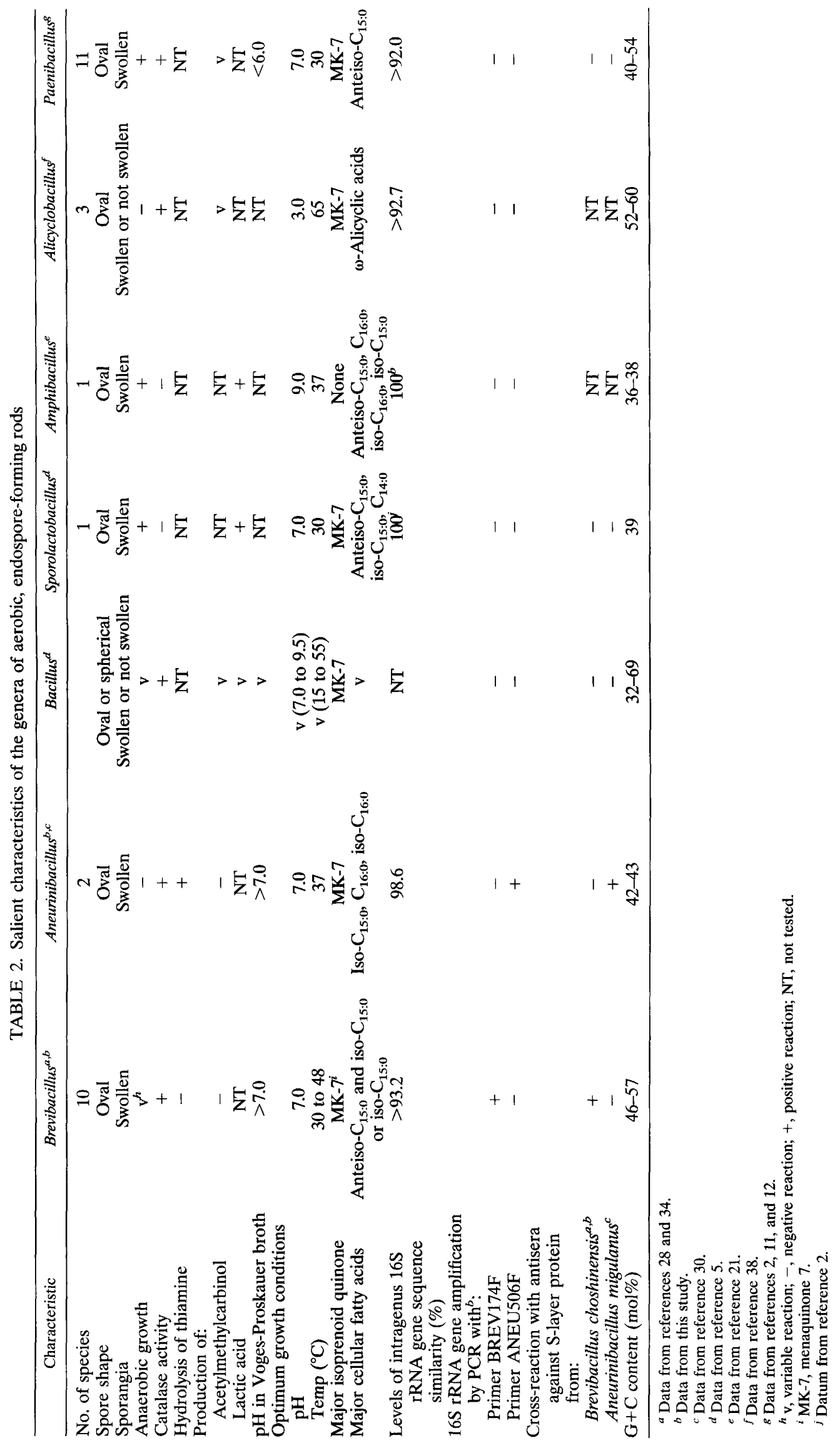


and Nakamura (19). The type strain is strain NRRL NRS-863 $(=$ JCM $9169=$ IFO $15716=$ CIP 104544).

Description of Brevibacillus borstelensis (Shida et al. 1995) comb. nov. The description of Brevibacillus borstelensis comb. nov. is identical to the descriptions given by Shida et al. (28) and Nakamura (19). The type strain is strain NRRL NRS-818 $(=$ JCM $9022=$ IFO $15714=$ CIP 104545).

Description of Brevibacillus laterosporus (Laubach 1905) comb. nov. The description of Brevibacillus laterosporus comb. nov. is identical to the description given by Claus and Berkeley (5). The type strain is strain JCM 2496 (= ATCC $64=$ CCM $2116=$ CIP $52.83=$ DSMZ $25=$ IFO $15654=$ IAM $12455=$ LMG 6931 = NCIMB 9367).

Description of Brevibacillus thermoruber (Manachini et al. 1985) comb. nov. The description of Brevibacillus thermoruber comb. nov. is identical to the description given by Manachini et al. (17). A specific S-layer protein is present in this organism (this study). The major quinone is menaquinone 7 (this study). The type strain is strain DSMZ 7064.

Description of Aneurinibacillus gen. nov. Aneurinibacillus (A.neu.ri.ni.ba.cil'lus. M. L. n. aneurinum, thiamine; L. dim. n. bacillus, small rod; M. L. masc. n. Aneurinibacillus, thiaminedecomposing small rod.) Cells are rod shaped ( 0.7 to 0.9 by 3.0 to $5.0 \mu \mathrm{m})$. Gram positive. Motile by means of peritrichous flagella. Ellipsoidal spores are formed in swollen sporangia. Colonies are flat, smooth, and yellowish gray, and no soluble pigment is produced on nutrient agar.

Strictly aerobic.

Catalase positive (Aneurinibacillus aneurinolyticus is weakly catalase positive). Oxidase variable.

The Voges-Proskauer reaction (production of acetylmethylcarbinol) is negative, and the $\mathrm{pH}$ in Voges-Proskauer broth is higher than 7.0 .

Dihydroxyacetone, hydrogen sulfide, and indole are not produced.

Nitrate is reduced to nitrite.

Casein, gelatin, starch, Tween 20, Tween 40, Tween 60 , Tween 80 , urea, and hippurate are not hydrolyzed. Hydrolysis of DNA is variable.

Tyrosine is decomposed. Thiamin is decomposed by thiamin hydrolase.

Phenylalanine is deaminated.

Citrate, propionate, alginate, gluconate, malonate, and tartrate are not utilized. Utilization of acetate, fumarate, lactate, succinate, L-glutamate, L-asparatate, L-malate, and $\alpha$-ketoglutarate is variable.

Nitrate is not utilized, and utilization of ammonium is variable.

The egg yolk reaction is positive.

Litmus milk is reduced and alkalinized.

Growth occurs at 20 to $50^{\circ} \mathrm{C}$ and at pHs 5.0 to 9.0. The optimum growth temperature and $\mathrm{pH}$ are $37^{\circ} \mathrm{C}$ and 7.0 , respectively. Growth occurs in the presence of $2 \% \mathrm{NaCl}$ and $0.001 \%$ lysozyme. Growth is variable in the presence of $0.02 \%$ sodium azide. Growth is inhibited in the presence of $5 \% \mathrm{NaCl}$.

Production of acid from $\mathrm{D}$-fructose, sucrose, trehalose, Dribose, glycerol, D-sorbitol, and L-sorbose is variable, and no gas is produced. No acid or gas is produced from D-glucose, L-arabinose, D-galactose, maltose, lactose, D-xylose, mannitol, D-cellobiose, salicin, D-mannose, melibiose, L-rhamnose, raffinose, inositol, erythritol, adonitol, and starch.

A specific S-layer protein is present.

The major cellular fatty acids are iso- $\mathrm{C}_{15: 0}$, iso- $\mathrm{C}_{16: 0}$, and $\mathrm{C}_{16: 0}$ acids.

The major quinone is menaquinone 7 .

The $\mathrm{G}+\mathrm{C}$ content ranges from 41.1 to $43.4 \mathrm{~mol} \%$.
The level of 16S rRNA gene sequence similarity for the members of this genus is $98.6 \%$. The 16S rRNA gene fragment is amplified by PCR by using primers ANEU506F and 1377R.

The type species is Aneurinibacillus aneurinolyticus.

Description of Aneurinibacillus aneurinolyticus (Shida et al. 1994) comb. nov. The description of Aneurinibacillus aneurinolyticus comb. nov. is identical to the description given by Shida et al. (30). The type strain is strain ATCC 12856 (= IAM 1077 = JCM 9024 = IFO 15521 = CIP 104007).

Description of Aneurinibacillus migulanus (Takagi et al. 1993) comb. nov. The description of Aneurinibacillus migulanus comb. nov. is identical to the descriptions given by Takagi et al. (34) and Shida et al. (30). The type strain is strain ATCC 9999 $(=$ JCM $8504=$ IFO $15520=$ CIP 103841).

\section{ACKNOWLEDGMENTS}

We thank K. Sano, R. Wakamatsu, and H. Shimada for technical assistance.

\section{REFERENCES}

1. Abe, M., and M. Kimoto. 1984. Distribution of two types of regular-array particles in cell wall of Bacillus aneurinolyticus (Kimura et Aoyama). Microbiol. Immunol. 28:841-846.

2. Ash, C., J. A. E. Farrow, S. Wallbanks, and M. D. Collins. 1991. Phylogenetic heterogeneity of the genus Bacillus revealed by comparative analysis of small-subunit-ribosomal RNA sequences. Lett. Appl. Microbiol. 13:202-206.

3. Ash, C., F. G. Priest, and M. D. Collins. 1993. Molecular identification of rRNA group 3 bacilli (Ash, Farrow, Wallbanks, and Collins) using a PCR probe test. Antonie Leeuwenhoek 64:253-260.

4. Avgustin, G., F. Wright, and H. J. Flint. 1994. Genetic diversity and phylogenetic relationships among strains of Prevotella (Bacteroides) ruminicola from the rumen. Int. J. Syst. Bacteriol. 44:246-255.

5. Claus, D., and R. C. W. Berkeley. 1986. Genus Bacillus Cohn 1872, p. 1105-1140. In P. H. A. Sneath, N. S. Mair, M. E. Sharpe, and J. G. Holt (ed.), Bergey's manual of systematic bacteriology, vol. 2. The Williams \& Wilkins Co., Baltimore.

6. Fahmy, F., J. Flossdorf, and D. Claus. 1985. The DNA base composition of the type strains of the genus Bacillus. Syst. Appl. Microbiol. 6:60-65.

7. Farrow, J. A. E., S. Wallbanks, and M. D. Collins. 1992. Phylogenetic analysis of the genera Planococcus, Marinococcus, and Sporosarcina and their relationship to members of the genus Bacillus. FEMS Microbiol. Lett. 93:167-172.

8. Felsenstein, J. 1985. Confidence limits on phylogenies: an approach using the bootstrap. Evolution 39:783-791.

9. Forsman, M., G. Sandström, and A. Sjöstedt. 1994. Analysis of 16S ribosomal DNA sequences of Francisella strains and utilization for determination of the phylogeny of the genus and for identification of strains by PCR. Int. J. Syst. Bacteriol. 44:38-46.

10. Fox, G. E., J. Wisotzkey, and P. Jurtshuk, Jr. 1992. How close is close: $16 \mathrm{~S}$ rRNA sequence identity may not be sufficient to guarantee species identity. Int. J. Syst. Bacteriol. 42:166-170.

11. Heyndrickx, M., K. Vandemeulebroecke, B. Hoste, P. Janssen, K. Kersters, P. De Vos, N. A. Logan, N. Ali, and R. C. W. Berkeley. 1996. Reclassification of Paenibacillus (formerly Bacillus) pulvifaciens (Nakamura 1984) Ash et al. 1994, a later subjective synonym of Paenibacillus (formerly Bacillus) larvae (White 1966) Ash et al. 1994, as a subspecies of $P$. larvae, with emended description of $P$. larvae as $P$. larvae subsp. larvae and $P$. larvae subsp. pulvifaciens. Int. J. Syst. Bacteriol. 46:270-279.

12. Heyndrickx, M., K. Vandemeulebroecke, P. Scheldeman, B. Hoste, K. Kersters, P. De Vos, N. A. Logan, A. M. Aziz, N. Ali, and R. C. W. Berkeley. 1995. Paenibacillus (formerly Bacillus) gordonae (Pichinoty et al. 1986) Ash et al. 1994 is a later subjective synonym of Paenibacillus (formerly Bacillus) validus (Nakamura 1984) Ash et al. 1994: emended description of $P$. validus. Int. J. Syst. Bacteriol. 45:661-668.

13. Hiraishi, H., and M. Kaneko. 1994. Use of polymerase chain reaction-amplified 16 S rRNA gene sequences to identify pink-pigmented bacteria found in a potable water treatment system. Bull. Jpn. Soc. Microb. Ecol. 9:55-65.

14. Jagoueix, S., J.-M. Bove, and M. Garnier. 1994. The phloem-limited bacterium of greening disease of citrus is a member of the $\alpha$ subdivision of the Proteobacteria. Int. J. Syst. Bacteriol. 44:379-386.

15. Kimura, M. 1980 . A simple method for estimating evolutionary rates of base substitutions through comparative studies of nucleotide sequences. J. Mol. Evol. 16:111-120.

16. Komagata, K., and K. Suzuki. 1987. Lipid and cell-wall analysis in bacterial systematics. Methods Microbiol. 19:161-207.

17. Manachini, P. L., M. G. Fortina, C. Parini, and R. Craveri. 1985. Bacillus thermoruber sp. nov., nom. rev., a red-pigmented thermophilic bacterium. Int. J. Syst. Bacteriol. 35:493-496. 
18. Nakamura, L. K. 1991. Bacillus brevis Migula 1900 taxonomy: reassociation and base composition of DNA. Int. J. Syst. Bacteriol. 41:510-515.

19. Nakamura, L. K. 1993. DNA relatedness of Bacillus brevis Migula 1900 strains and proposal of Bacillus agri sp. nov., nom. rev., and Bacillus centrosporus sp. nov., nom. rev. Int. J. Syst. Bacteriol. 43:20-25.

20. Nielsen, P., F. A. Rainey, F. A. Outtrup, F. G. Priest, and D. Fritze. 1994 Comparative $16 S$ rDNA sequence analysis of some alkaliphilic bacilli and the establishment of a sixth rRNA group within the genus Bacillus. FEMS Microbiol. Lett. 117:61-66.

21. Niimura, Y., E. Koh, F. Yanagida, K. Suzuki, K. Komagata, and M. Kozaki. 1990. Amphibacillus xylanus gen. nov., sp. nov., a facultatively anaerobic sporeforming xylan-digesting bacterium which lacks cytochrome, quinone, and catalase. Int. J. Syst. Bacteriol. 40:297-301.

22. Priest, F. G. 1993. Systematics and ecology of Bacillus, p. 3-16. In A. L Sonenshein, J. Hoch, and R. Losick (ed.), Bacillus subtilis and other grampositive bacteria: biochemistry, physiology, and molecular genetics. American Society for Microbiology, Washington, D.C

23. Rainey, F. A., D. Fritze, and E. Stackebrandt. 1994. The phylogenetic diversity of thermophilic members of the genus Bacillus as revealed by $16 \mathrm{~S}$ rDNA analysis. FEMS Microbiol. Lett. 115:205-212.

24. Rössler, D., W. Ludwig, K. H. Schleifer, C. Lin, T. J. McGill, J. D. Wisotzkey, P. Jurtshuk, Jr., and G. E. Fox. 1991. Phylogenetic diversity in the genus Bacillus as seen by $16 \mathrm{~S}$ rRNA sequencing studies. Syst. Appl. Microbiol. 14:266-269.

25. Saitou, N., and M. Nei. 1987. A neighbor-joining method: a new method for reconstructing phylogenetic trees. Mol. Biol. Evol. 4:406-425.

26. Sambrook, J., E. F. Fritsch, and T. Maniatis. 1989. Molecular cloning: laboratory manual, 2nd ed. Cold Spring Harbor Laboratory Press, Cold Spring Harbor, N.Y.

27. Sanger, F., S. Nicklen, and A. R. Coulson. 1977. DNA sequencing with chain-terminating inhibitors. Proc. Natl. Acad. Sci. USA 74:5463-5467.

23. Shida, O., H. Takagi, K. Kadowaki, L. K. Nakamura, and K. Komagata. 1995. Proposal of Bacillus reuszeri sp. nov., Bacillus formosus sp. nov., nom. rev., and Bacillus borstelensis sp. nov., nom. rev. Int. J. Syst. Bacteriol. 45: $93-100$.
29. Shida, O. H. Takagi, K. Kadowaki, S. Udaka, and K. Komagata. 1994. Bacillus galactophilus is a later subjective synonym of Bacillus agri. Int. J. Syst. Bacteriol. 44:172-173.

30. Shida, O., H. Takagi, K. Kadowaki, H. Yano, M. Abe, S. Udaka, and K. Komagata. 1994. Bacillus aneurinolyticus sp. nov., nom. rev. Int. J. Syst. Bacteriol. 44:143-150.

31. Shida, O., H. Takagi, K. Kadowaki, H. Yano, and K. Komagata. 1996. Differentiation of species in the Bacillus brevis group and the Bacillus aneurinolyticus group based on the electrophoretic whole-cell protein pattern. Antonie Leeuwenhoek 70:31-39.

32. Spanka, R., and D. Fritze. 1993. Bacillus cohnii sp. nov., a new, obligately alkaliphilic, oval-spore-forming Bacillus species with ornithine and aspartic acid instead of diaminopimelic acid in the cell wall. Int. J. Syst. Bacteriol. 43:150-156.

33. Suzuki, T., and K. Yamasato. 1994. Phylogeny of spore-forming lactic acid bacteria based on 16S rRNA gene sequences. FEMS Microbiol. Lett. 115 13-18.

34. Takagi, H., O. Shida, K. Kadowaki, K. Komagata, and S. Udaka. 1993. Characterization of Bacillus brevis, with descriptions of Bacillus migulanus sp. nov., Bacillus choshinensis sp. nov., Bacillus parabrevis sp. nov., and Bacillus galactophilus sp. nov. Int. J. Syst. Bacteriol. 43:221-231.

35. Thompson, J. D., D. G. Higgins, and T. J. Gibson. 1994. CLUSTAL W improving the sensitivity of progressive multiple sequence alignment through sequence weighting, position-specific gap penalties and weight matrix choice. Nucleic Acids Res. 22:4673-4680.

36. Towbin, H., T. Staehlin, and J. Gordon. 1979. Electrophoretic transfer of proteins from polyacrylamide gels to nitrocellulose sheets: procedure and some applications. Proc. Natl. Acad. Sci. USA 76:4350-4354

37. Udaka, S. 1976. Screening for protein-producing bacteria. Agric. Biol. Chem 40:523-528.

38. Wisotzkey, J. D., P. Jurtshuk, Jr., G. E. Fox, G. Deinhard, and K. Poralla 1992. Comparative sequence analysis on the 16S rRNA (rDNA) of Bacillus acidocaldarius, Bacillus acidoterrestris, and Bacillus cycloheptanicus and proposal for creation of a new genus, Alicyclobacillus gen. nov. Int. J. Syst. Bacteriol. 42:263-269. 